\title{
Antimicrobial functionalized genetically engineered spider silk
}

\author{
Sílvia C. Gomes ${ }^{\mathrm{a}, \mathrm{b}, \mathrm{c}}$, Isabel B. Leonor ${ }^{\mathrm{a}, \mathrm{b}}$, João F. Mano ${ }^{\mathrm{a}, \mathrm{b}}$, Rui L. Reis ${ }^{\mathrm{a}, \mathrm{b}, * *}$, David L. Kaplan ${ }^{\mathrm{c}, *}$ \\ a 3B's Research Group - Biomaterials, Biodegradables and Biomimetics, Department of Polymer Engineering, University of Minho, Headquarters of the European Institute of \\ Excellence on Tissue Engineering and Regenerative Medicine, AvePark, Zona Indústrial da Gandra, 4806-909 Caldas das Taipas, Guimarães, Portugal \\ ${ }^{\mathrm{b}}$ Institute for Biotechnology and Bioengineering (IBB), PT Government Associated Laboratory, Braga, Portugal \\ ${ }^{\mathrm{c}}$ Departments of Biomedical Engineering, Chemistry and Physics, Tufts University, 4 Colby Street, Medford, MA 02155, USA
}

\section{A R T I C L E I N F O}

\section{Article history:}

Received 8 January 2011

Accepted 19 February 2011

Available online 31 March 2011

\section{Keywords:}

Spider silk

Antimicrobial activity

Recombinant proteins

Self-assembly

Cell viability

Bone tissue engineering

\begin{abstract}
A B S T R A C T
Genetically engineered fusion proteins offer potential as multifunctional biomaterials for medical use. Fusion or chimeric proteins can be formed using recombinant DNA technology by combining nucleotide sequences encoding different peptides or proteins that are otherwise not found together in nature. In the present study, three new fusion proteins were designed, cloned and expressed and assessed for function, by combining the consensus sequence of dragline spider silk with three different antimicrobial peptides. The human antimicrobial peptides human neutrophil defensin 2 (HNP-2), human neutrophil defensins 4 (HNP-4) and hepcidin were fused to spider silk through bioengineering. The spider silk domain maintained its self-assembly features, a key aspect of these new polymeric protein biomaterials, allowing the formation of $\beta$-sheets to lock in structures via physical interactions without the need for chemical crosslinking. These new functional silk proteins were assessed for antimicrobial activity against Gram Escherichia coli and Gram + Staphylococcus aureus and microbicidal activity was demonstrated. Dynamic light scattering was used to assess protein aggregation to clarify the antimicrobial patterns observed. Attenuated-total reflectance Fourier transform infrared spectroscopy (ATR-FTIR) and circular dichroism (CD) were used to assess the secondary structure of the new recombinant proteins. In vitro cell studies with a human osteosarcoma cell line (SaOs-2) demonstrated the compatibility of these new proteins with mammalian cells.
\end{abstract}

(c) 2011 Elsevier Ltd. All rights reserved.

\section{Introduction}

Around 350 billion dollars are spent worldwide on organ replacement therapies to prolong the lives of more than 20 million patients. Most organ replacement surgeries rely on the use of organometallic devices, most of which were developed in the 1960s $[1,2]$. Tissue engineering is an emerging interdisciplinary field focused on the development of tissues and organs that can be used to replace damaged and failing tissues and organs. One of the major goals of tissue engineering is to replace permanent implanted prostheses with temporary implants with reconstructive and regenerative characteristics capable of directing the full restoration of normal tissue structure and function in the body; thus they must

\footnotetext{
* Corresponding author. Tel.: +1 6176273251.

** Corresponding author. 3B's Research Group - Biomaterials, Biodegradables and Biomimetics, Department of Polymer Engineering, University of Minho, Headquarters of the European Institute of Excellence on Tissue Engineering and Regenerative Medicine, AvePark, Zona Indústrial da Gandra, 4806-909 Caldas das Taipas, Guimarães, Portugal.

E-mail addresses: rgreis@3bs.uminho.pt (R.L. Reis), david.kaplan@tufts.edu (D.L. Kaplan).
}

be fully degradable over time [3]. Achieving this goal would revolutionize healthcare treatment as well as patient well being [4]. The biomaterials field contributes directly toward this goal through the development of polymers with diverse mechanical and biological characteristics [5-8] that can be used to facilitate the regeneration of damaged tissues. In the case of bone repair, meeting mechanical and functional requirements at the implant site remains a challenge for most polymeric biomaterials $[9,10]$.

In the present work, spider silk was selected for the core polymer due to its potential as a biomaterial to meet the requirements for both mechanical stability and biocompatibility necessary for bone tissue engineering, as well as its accessibility to bioengineering [11-13]. Furthermore, recombinant DNA technologies allow the generation of spider silk proteins fused to other protein domains not normally found in spider silks, thereby expanding the function of these protein polymers. These new chimeric or multifunctional spider silk-like molecules combine the properties of silk (e.g., self-assembly, robust material properties and physical cross-linking to stabilize materials) with characteristics of the new domains added to the silk. These types of new multifunctional polymeric biomaterials provide a new route to control biomaterial 
properties related to both material features and biological interactions. The addition of antimicrobial peptides to reduce or control infections at the site of implantation was the direction sought in the present study.

There are more than 600 peptides known with antimicrobial activity, most with broad activity against different microorganisms, including Gram+ and Gram- bacteria, virus, protozoa and fungi [14]. The bactericidal activity of these molecules starts with direct binding to the lipid bilayer forming the bacteria membrane. After this interaction with the membrane the bactericidal peptides acquire an amphiphilic three-dimensional conformation where the positive side of the antimicrobial molecules interact directly with the negatively charged lipid head-groups. This interaction results in the formation of pores through the bacterial membrane $[15,16]$. A prominent feature of defensins is the six cysteine residues which form three disulphide bonds. Cysteine residues confer cationic nature to defensins and the initial association between these peptides and bacteria occurs through electrostatic interactions between the cationic peptides and the negatively charged lipid forming the outer membrane [17]. Moreover, these peptides play an important role in inflammation [18], and chemotaxis for monocytes and $T$ cells to activate the acquired immune response system [19]. These peptides also intervene in the wound healing [20] by stimulating the proliferation of fibroblasts and epithelial cells [21,22], induce neovasculogenesis [23] and mobilize cytokines [24]. Human $\alpha$-defensins are cationic cysteine-rich peptides containing between 29 and 35 amino acids $[25,26]$. Six $\alpha$-defensins have been described, human neutrophil defensins 1 to 4 (HNP-1, HNP-2, HNP-3 and HNP-4) [27], which are expressed in neutrophils, and human defensins 5 to 6 (HD-5 and HD-6) expressed by Paneth cells of the small intestine and by the epithelial cells of the female urogenital track [28]. HNP-2 manifests bactericidal activity against both Gram+ and Gram- bacteria [29]. HNP-4 was considered more effective against Gram- Escherichia coli and Enterobacter aerogenes. Moreover, HNP-4 was more effective than HNP-1, HNP-2 and HNP-3 in protecting human peripheral blood mononuclear cells from infection by both X4 and R5 HIV-1 strains [30].

Resembling the human neutrophil defensins described above, hepcidin (also named LEAP-1 for liver expressed antimicrobial peptide), is also a cysteine-rich peptide. Hepcidin mRNA was found primarily in the liver and was isolated initially from human blood [31] and later detected in urine [32].Hepcidin exhibits bactericidal and fungicidal activity with activity against Gram+ and Grambacteria. Hepcidin was active against the Gram- E. coli ML35 strain and Neisseria cinerea, and against the Gram+Staphylococcus aureus, Staphylococcus epidermis, Staphylococcus carnosus, Bacillus cereus, Bacillus megaterium, Bacillus subtilis, Micrococcus luteus and group B Streptococcus [31-35]. After incubation of K562 cells (AmericanType Culture Collection leukemic cell line CCL-243) for $15 \mathrm{~h}$ with hepcidin at a concentration of $30 \mu \mathrm{M}$, viability of $74 \%$ was found [32]. Thus the cytotoxicity of hepcidin was much lower than after incubation of these cells with $30 \mu \mathrm{M} \alpha$-defensin HNP-1, where only $9 \%$ of the cells were viable over the same time frame [32]. Based on the antimicrobial activities of HNP-2, HNP-4 and hepcidin, these peptides were selected for fusion with the silk protein major ampullate spidroin protein (MaSpI) in the present study. The silk was selected as the main protein component as it has been shown to self-assemble into impressively strong and tough protein-based biomaterials, is biodegradable due to the activity of proteases, and can be formed into a range of material formats using water [36-38].

Due to the relatively low cytotoxicity, resistance to microorganism adaptation and broad spectra of action some antimicrobial peptides are considered strong candidates to be used in coatings of polymeric surfaces to help preventing microbial contamination. However, few studies have addressed this topic. In the past few years different antimicrobial peptides were expressed together with a carbohydrate binding module from Clostridium thermocellum, to enable attachment to different cellulosic surfaces for antimicrobial properties $[39,40]$. The chemical coupling of antimicrobial peptides to different types of surfaces, such as: polyamide resins [41], polystyrene-polyethylene glycol beads [42-44] and titanium [45], has also been reported. To our knowledge this is the first study describing fusion proteins combining both silk and antimicrobial domains.

The goal of the present study was to construct three new fusion proteins combining spider silk with antimicrobial features hepcidin, HNP-2 and HNP-4 (Fig. 1A). Three different antimicrobial peptides were selected due to the possible decrease in activity when the peptides were coupled with the spider silk. In this way, the activities of the three different fusion proteins could be compared to identify the most useful sequence for biomaterials formation and characterization. The silk domain in the proteins carries six repeats of the consensus repeat for the native sequence of the protein major ampullate dragline silk I (MaSpI) from the spider Nephila clavipes. Each silk repeat is formed by a hydrophilic GGX motif and a hydrophobic poly-A motif (Fig. 1B).The three different silk-antimicrobial fusions were successfully expressed and characterized for structure and function. The antibacterial activity was studied by radial diffusion. Secondary structure of the recombinant proteins was assessed by attenuated-total reflectance Fourier transform infrared spectroscopy (ATR-FTIR) and circular dichroism (CD). Dynamic light scattering (DLS) was used to assess aggregation related to antimicrobial activity in solution. Finally, cytotoxicity tests were performed to confirm the potential utility of these new multifunctional silk proteins in contact with mammalian cells.

\section{Materials and methods}

\subsection{Cloning HNP-2, HNP-4 and hepcidin into pET30L vector containing silk modules}

Vector pET30a + (Novagen, San Diego CA) was used for the construction of the vector pET30L carrying the silk block copolymer using procedures described in our previous work [46].The silk block copolymer carries six repeats of the consensus repeat for the native sequence of the protein major ampullate dragline silk I from the specie $N$. clavipes. This spider silk block copolymer $(6 \mathrm{mer})$ was cloned with six histidine residues to facilitate protein purification, and with two restriction sites, one for SpeI and another NheI, flanking its edges to allow the addition of other DNA [46].

The HNP-2, HPN-4 and hepcidin cDNA sequences were prepared through the annealing of synthetic single strand oligonucleotide sequences (Invitrogen, CA, USA): HNP-2 top and HNP-2 bottom, HNP-4 top and HNP-4 bottom and hepcidin top and hepcidin bottom. The annealing reactions were carried out by decreasing the temperature of the oligonucleotide solution from $95{ }^{\circ} \mathrm{C}$ to $20{ }^{\circ} \mathrm{C}$ with a gradient of $0.1^{\circ} \mathrm{C} / \mathrm{s}$. The presence of the annealed products was verified with $5 \%$ agarose gels. At the edges of each cDNA sequence restriction sites were present for SpeI and for Nhel for the insertion of the cDNA sequences into the vector pET30L. This vector already carried the DNA encoding the silk block copolymer. For the insertion of the cDNA sequences into pET30L, the vector was digested with SpeI (New England Biolabs, MA, USA, R0133S), dephosphorylated with calf intestinal phosphatase (CIP) (New England Biolabs, M0290S) and run on $0.8 \%$ agarose gels. The linearized vector was purified using the QIAquick gel extraction kit (Qiagen, CA, USA, 28706). The cDNA sequences were double digested with $\mathrm{SpeI}$ and NheI and the digestion products run in a $0.8 \%$ gel and the bands for the cDNA sequences were purified using a QIAquick gel extraction kit. HNP-2, HPN-4 and hepcidin cDNA were ligated individually to the silk 6mer present in the expression vector pET30L using T4 DNA ligase enzyme (New England Biolabs, M0202S).

E. coli DH5 $\alpha$ cells (Invitrogen, 18258-012) were transformed with the ligation products and successful transformants were identified by plating on agar plates containing $25 \mu \mathrm{g} / \mathrm{mL}$ kanamycin. The presence of the HNP-2, HPN-4 and hepcidin inserts was confirmed by DNA sequencing (Tufts Core Facility, Boston, MA) using T7 primers and the new constructs were named: 6 mer + HNP-2, 6 mer + HNP -4 and 6 mer + hepcidin.

\subsection{Protein expression and purification}

The 6 mer, 6 mer + HNP-2, 6mer+HNP-4 and 6 mer + hepcidin were expressed in E. coli RY-3041 strain, a mutant strain of E. coli BLR(DE3) defective in the expression of SlyD protein $[46,47]$. SlyD protein was reported in previous studies as co-eluting 


\title{
A
}

\section{6mer+HNP-2}

SGRGGLGGQGAGAAAAAGAGQGGYGGLGSQGTSGRGGLGGQGAGAAAAAGAGQGGYGGLGSQ GTSGRGGLGGQGAGAAAAAGGAGQGGYGGLGSQGTSGRGGLGGQGAGAAAAAGGAGQGG GGLG SQGTSGRGGLGGQGAGAAAAAGGAGQGGYGGLGSQGTSGRGGLGGQGAGAAAAAGGGQGGYGG

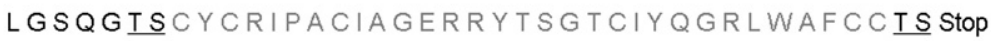

\section{6mer+HNP-4}

SGRGGLGGQGAGAAAAAGGAGQGGYG L GSQGTSGRGGLGGQGAGAAAAAG A GQGGYGGLGSQ GTSGRGGLGGQGAGAAAAAGGAGQGGYGGLGSQGTSGRGGLGGQGAGAAAAAGGAGQGGYGGLG SQGTSGRGGLGGQGAGAAAAAGGAGQGGYGLGSQGTSGRGGLGGQGAGAAAAAGAGQGGYGG LGSQG TSVCSCRLVFCRRTELRVTSGNCCLIGGVSFTYCCTRV $\underline{\text { TS Stop }}$

\author{
6mer+hepcidin \\ B \\ Hydrophobic Block \\ GAGAAAAAGAG \\ Hydrophilic Block \\ QGGYGGLGSQGTSGRGGLGGQ
}

SGRGGLGGQGAGAAAAAGGAGQGGYGGLGSQGTSGRGGLGGQGAGAAAAAGGAGQGGYGGLGSQ GTSGRGGLGGQGAGAAAAAGGAGQGYGGLGSQGTSGRGGLGGQGAGAAAAAGAGQGGYGGLG SQGTSGRGGLGGQGAGAAAAAGGAGQGGYGLGSQGTSGRGGLGGQGAGAAAAAGGAQGGYGG

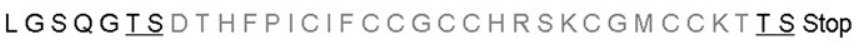

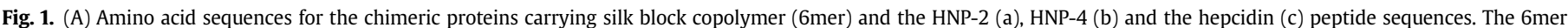

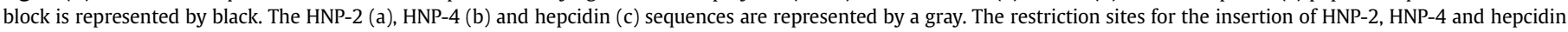
sequences are underlined. (B) Amino acid sequences for the hydrophobic and hydrophilic blocks present in each of the six units forming the silk block copolymer (6mer).

with silk proteins during purification by Ni-NTA affinity chromatography due to the histidine content, an amino acid with known affinity for Ni-NTA columns. In E. coli RY-3041 strain the C-terminus, with the high content of histidines, of the SlyD protein was deleted to avoid co-elution with expressed recombinant proteins with his fusion tags [47]. Cells were cultivated at $37{ }^{\circ} \mathrm{C}$ in LB medium, with $25 \mu \mathrm{g} / \mathrm{mL}$ kanamycin until an $\mathrm{OD}_{600}$ between 0.9 and 1 was reached. At this point expression was induced with isopropyl $\beta$-D-thiogalactoside (IPTG, Invitrogen, 15529019) to a final concentration of $0.5 \mathrm{~mm}$. After $2 \mathrm{~h}$ of expression the cells were harvested by centrifugation at $6500 \mathrm{rpm}$. The cell pellet was resuspended in denaturating buffer ( $100 \mathrm{~mm} \mathrm{NaH}_{2} \mathrm{PO}_{4}, 10 \mathrm{~mm}$ Tris $\mathrm{HCl}, 8 \mathrm{~m}$ urea, $\mathrm{pH}$ 8.0) and left overnight with stirring for complete cell lysis. Insoluble cell fragments and soluble proteins present in the cell lysate were separated through centrifugation at $11000 \mathrm{rpm}$. The supernatant was mixed with Ni-NTA resin (Qiagen, 30250) and left for $2 \mathrm{~h}$ with stirring. The supernatant/Ni-NTA resin mixture was loaded onto a glass Econo-column (Biorad) and washed several times with denaturating buffer at $\mathrm{pH} 8.0$ and then $\mathrm{pH}$ 6.0. The 6 mer+HNP-2, 6mer+HNP-4 and 6 mer + hepcidin proteins were eluted using denaturating buffer at $\mathrm{pH}$ 4.5. The purified proteins were dialyzed first in a $20 \mathrm{~mm}$ sodium acetate buffer followed by extensive dialysis in MQ water using cellulose ester snake skin membranes with a 100-500 Da molecular weight cut off (Spectra/ Por Biotech, 131054). The dialyzed proteins were lyophilized in a LabConco lyophilizer. Protein sequencing (Tufts Core Facility, Boston, MA), SDS-PAGE and western blot were used to confirm protein identity.

\subsection{Protein identification by western blot}

Proteins were mixed with NuPAGE LDS sample buffer (Invitrogen, NP0007) and heated to $80{ }^{\circ} \mathrm{C}$ for $10 \mathrm{~min}$.The samples were separated using a Bis-tris $4-12 \%$ gel (Invitrogen, NP0321BOX). For the western blot the His-Tag AP western kit provided by Novagen, EMD Biosciences, NJ, USA (70972) was used with the protocol provided. Briefly, bands were electro-transferred onto a nitrocellulose membrane at $30 \mathrm{~V}$ for $16 \mathrm{~h}$. Membranes were blocked for $1 \mathrm{~h}$ with $3 \%$ bovine serum albumin (BSA) in TBS buffer (blocking solution). After washing with tris buffered solution (TBS buffer) the membrane was incubated for $1 \mathrm{~h}$ with mouse anti-histidine monoclonal antibody (Novagen) diluted 1:1000 in blocking solution. Following proper washing with TBSTT buffer (TBS with tween 20) the membrane was incubated for $1 \mathrm{~h}$ with goat anti-mouse IgG AP conjugated antibody diluted 1:5000 in blocking solution.
Colorimetric detection was performed with developing solution of 5-bromo-4chloro-3-indolylphosphate (BCIP) and nitrobluetetrazolium (NBT).

\subsection{Film formation and ATR-FTIR secondary structure analysis}

Recombinant 6 mer + HNP-2, 6mer+HNP-4, 6 mer + hepcidin and 6 mer proteins were dissolved in MQ water to a final concentration of $2 \%(\mathrm{w} / \mathrm{v})$.Then $60 \mu \mathrm{l}$ of each protein solution was cast onto a non adherent polystyrene surface and left to dry at room temperature. The films obtained were treated with $70 \%$ methanol for $2 \mathrm{~h}$ to induce the transition of secondary structure from random coil to $\beta$-sheet. This treatment produced films with improved mechanical properties and more resistant to dissolution in water or other aqueous environments such as culture media. For cell studies the films were treated with $70 \%(w / w)$ ethanol solution for sterilization purposes. ATR-FTIR (Jasco Inc., MD, USA, model FT/IR-6200) was performed before and after methanol treatment of the films to investigate secondary structure. Spectra were collected in absorption mode at $8 \mathrm{~cm}^{-1}$ resolution and a 4000 to $400 \mathrm{~cm}^{-1}$ region was scanned. The quantification of the secondary structure was based on the analysis of the amide I and amide II regions $\left(1700-1450 \mathrm{~cm}^{-1}\right)$. The average percentage for the secondary structures, mainly $\beta$-sheet content for the $6 \mathrm{mer}$ (control situation), $6 \mathrm{mer}+\mathrm{HNP}-2,6 \mathrm{mer}+\mathrm{HNP}-4$ and $6 \mathrm{mer}+$ hepcidin proteins was calculated through the integration of the area of each deconvoluted curve followed by the normalization of the obtained value to the total area of the amide I and amide II regions [48]. OPUS deconvolution software (Bruker optics, Billerica, MA, USA) was used for spectrum deconvolution and each deconvoluted spectrum was curve-fitted with Gaussian bands using the peak pick function. After curve-fitting information concerning the percentage of amide I and II regions, bandwidth and band position, referring to $\beta$-sheet or $\alpha$-helix conformations, was obtained [49].

\subsection{Antibacterial assay}

The purified recombinant proteins were tested for antimicrobial activity against E. coli (American-Type Culture Collection ATCC 25922, VA, USA,) and S. aureus (ATCC 25923), purchased from American-Type Culture Collection. The radial diffusion assay [50] was used to test three concentrations of the purified proteins dissolved in phosphate buffer ( $\mathrm{pH} 7.4$ ): 10, 50 and $100 \mu \mathrm{g} / \mathrm{mL}$. The 6 mer protein solutions were used as controls. E. coli and S. aureus lawns were plated on LB-agar plates, using 
liquid $E$. coli and $S$. aureus cultures grown overnight at $37^{\circ} \mathrm{C}$. A biopsy punch $8 \mathrm{~mm}$ in diameter was use to cut circles from filter paper (Whatman, Piscataway, NJ, USA, 09-845B) that were used as blank susceptibility disks. For sterilization, the disks were immersed in a 70\% (v/v) ethanol solution for $1 \mathrm{~h}$ and left to dry for $2 \mathrm{~h}$ in a hood. After drying, the discs were immersed in the different protein solutions, placed on the bacterial lawns and incubated overnight at $37^{\circ} \mathrm{C}$. The zones of growth inhibition formed around the susceptibility disks were measured using Image software. The 6 mer protein was used as a negative control in order to exclude the effect from silk itself and from possible contaminants derived from the expression and purification processes. Experiments were carried out in triplicate.

\subsection{Aggregation}

A Zetasizer NanoZS instrument (ZEN3600, MALVERN Instruments, Worcestershire, UK) was used for DLS measurements. DLS was performed on solutions at the same concentrations used for the antibacterial assay (section 2.5): 10, 50 and $100 \mu \mathrm{g} / \mathrm{mL}$. Samples were prepared with phosphate buffer ( $\mathrm{pH} 7.4)$. The scattering light was collected at a $173^{\circ}$ scattering angle.

\subsection{Circular dichroism spectroscopy}

Circular Dichroism (CD) spectroscopy was performed on an Aviv, Model 410 (Biomedical, Inc. NJ USA) instrument. The spectra were collected between 260 and $180 \mathrm{~nm}$ with a step size of $1 \mathrm{~nm}$, an averaging time of $1 \mathrm{~s}$ and five scans were collected for each sample. A baseline spectrum was subtracted from the samples. Sample cells with a $0.1 \mathrm{~cm}$ path length were used and measurements were performed with $1 \mathrm{mg} / \mathrm{mL}$ protein solutions in phosphate buffer ( $\mathrm{pH} 7.4)$.

\subsection{Cytotoxicity assay}

Human osteosarcoma cell line (SaOs-2) is an immortalized cell line with osteoblastic phenotype (HTB-85) and was purchased from the American-Type Culture Collection. Cells were cultured using basal medium consisting in Dulbecco's modified Eagle's medium (DMEM) supplemented with $10 \%(\mathrm{v} / \mathrm{v})$ fetal bovine serum (FBS), $1 \%$ penicillin-streptomycin $(\mathrm{v} / \mathrm{v})$, at $37{ }^{\circ} \mathrm{C}$ with $5 \% \mathrm{CO}_{2}$ in a humidified environment. After reaching confluence, cells were harvested with trypsin/EDTA and after counting cells they were seeded at $3.0 \times 10^{3}$ cells $/ \mathrm{cm}^{2}$ in a 96 well plate coated with the four different types of protein films, 6mer+HNP-2, 6mer+HNP-4, 6 mer + hepcidin, 6 mer (control) films, prepared as in section 2.3. Tissue culture plate (TCP) was used as a positive control in this assay. The Alamar blue (Invitrogen, DAL1025) assay was used to determine cell viability/proliferation after three days of culture. Alamar Blue reagent was added to the growth media in a 1:10 dilution ratio and data was collected using fluorescence at 530-560 nm excitation and $590 \mathrm{~nm}$ emission [51]. A standard curve with the different cell numbers $(10,000,5000,2500$ and 0 ) on the $x$ axis and the corresponding fluorescence values on the $y$ axis were used to determine the cell numbers as detailed by the supplier.

\subsection{Statistical analysis}

SPSS 17.0 was used to perform statistical analysis. The Shapiro-Wilk test was use to test for the normality of the data. To test for significant differences between different experimental groups (6mer+HNP-2, 6mer+HNP-4, 6mer + hepcidin, 6 mer) one-way ANOVA with a Dunet's T3 post hoc comparison was used. Statistical significance was defined as $p<0.05$.

\section{Results}

\subsection{Cloning and expression of HNP-2, HNP-4 and hepcidin}

The presence of the HNP-2, HNP-4 and hepcidin inserts in the cloning vector containing the silk modules was confirmed through DNA sequencing (Tufts Core Facility, Boston, MA). SDS-PAGE and Western blots (Fig. 2) indicated that both expression and purification of 6 mer (control), 6mer+HNP-2, 6mer+HNP-4 and $6 \mathrm{mer}+$ hepcidin proteins was successful and protein sequencing at Tufts Core Facility, Boston, MA confirmed the N-terminal amino acid sequence for the all three proteins. For 6 mer+HNP-2, 6 mer+HNP-4, 6mer + hepcidin and 6mer proteins the theoretical molecular weights were approximately 24.6, 25, 24.1 and $21.8 \mathrm{kDa}$, respectively, and with SDS-PAGE and Western blot assays bands were observed at around $28 \mathrm{kDa}$ (Fig. 2). Furthermore, with SDSPAGE and Western blot the presence of dimers and multimers corresponding to aggregation products of the monomer forms were also observed, together with pre-terminated sequences representing proteins whose expression was incomplete and therefore present a lower molecular weight than the monomeric complete proteins. After purification, dialysis and lyophilization the yield of 6mer+HNP-2, 6mer+HNP-4, 6mer + hepcidin were approximately $12 \mathrm{mg} / \mathrm{L}$ for each of the proteins, and for the $6 \mathrm{mer}$ control protein the yield was $25 \mathrm{mg} / \mathrm{L}$.

\subsection{Film formation and secondary structure analysis}

The ATR-FTIR spectra for the 6mer (control), 6mer+HNP-2, 6 mer+HNP-4 and 6mer + hepcidin films, before and after methanol treatment, exhibited strong amide I (1700-1600 $\left.\mathrm{cm}^{1}\right)$ and amide II (1600-1500 $\left.\mathrm{cm}^{-1}\right)$ regions (Fig. 3). Before methanol treatment the ATR-FTIR spectra for 6 mer+HNP-2, 6mer+HNP-4, 6 mer + hepcidin and 6mer protein films exhibited vibrational modes in the range of $1650-1647 \mathrm{~cm}^{-1}$, amide I region, indicative of helix/random coil conformations. After methanol treatment two peaks appeared, one in the range of $1620-1630 \mathrm{~cm}^{-1}$, amide I region, and another in the range of $1510-1530 \mathrm{~cm}^{-1}$, amide II region. Both peaks were indicative of antiparallel $\beta$-sheet structures $[46,52,53]$. Spectra deconvolution revealed the percentage of helix/ random coil conformations and of antiparallel $\beta$-sheet structures for the 6 mer+HNP-2, 6mer+HNP-4, 6mer + hepcidin and for 6mer films before and after methanol treatment (Fig. 3). For all four films an increase of $\beta$-sheet content was observed with a corresponding decrease in the helix/random coil conformation after methanol treatment (Fig. 3). The $\beta$-sheet content after methanol treatment was similar for all four constructs ranging between $39.8 \%$ for 6 mer+HNP-2 and $42.8 \%$ for 6 mer+HNP-4. For the 6 mer and the 6 mer + hepcidin films the content was $40.8 \%$ and $41.9 \%$, respectively.

\subsection{Antimicrobial activity of $6 m e r+H N P-2,6 m e r+H N P-4$ and 6 mer + hepcidin proteins}

The antimicrobial activity of 6 mer $+\mathrm{HNP}-2,6 \mathrm{mer}+\mathrm{HNP}-4$ and 6 mer + hepcidin against the Gram- E. coli and the Gram+S. aureus was studied using the radial diffusion assay. The three proteins displayed antimicrobial activity against $E$. coli with the formation of inhibition zones at all three concentrations tested (Figs. 4 and 5). In the case of E. coli, 6mer+HNP-4 and 6mer + hepcidin registered higher bactericidal values when compared with the 6mer+HNP-2 peptide. For all three proteins the highest antimicrobial activity was at a concentration of $10 \mu \mathrm{g} / \mathrm{mL}(p<0.05)$. Against $S$. aureus there was a decrease in bactericidal activity for all the three peptides when compared to $E$. coli, based on the smaller diameter inhibition zone, especially in the case of the 6mer + hepcidin and 6mer+HNP2 (Fig. 5). For the proteins tested there was a decrease in the bactericidal activity from 10 to $100 \mu \mathrm{g} / \mathrm{mL}(p<0.05)$. The $6 \mathrm{mer}$ protein was used as a negative control and no inhibition zones were detected for the three concentrations tested (Fig. 5).

\subsection{Aggregation}

For the 6 mer, 6 mer+HNP-2, 6mer+HNP-4 and 6 mer + hepcidin, DLS measurements detected an increase in particle diameter with increasing protein concentration, indicating that aggregation was dependent on protein concentration (Fig. 6). In the case of the $6 \mathrm{mer}$, only one peak was detected for each of the three concentrations measured. In contrast, for 6mer+HNP-2, 6mer+HNP-4 and 6 mer + hepcidin two peaks were always detected, except for $6 \mathrm{mer}+$ hepcidin at concentration of $100 \mu \mathrm{g} / \mathrm{mL}$. These data indicated the coexistence of smaller (between 24 and $44 \mathrm{~nm}$ ) and larger (between 110 and $238 \mathrm{~nm}$ ) aggregates, the size of which decreased with decreasing protein concentration. 


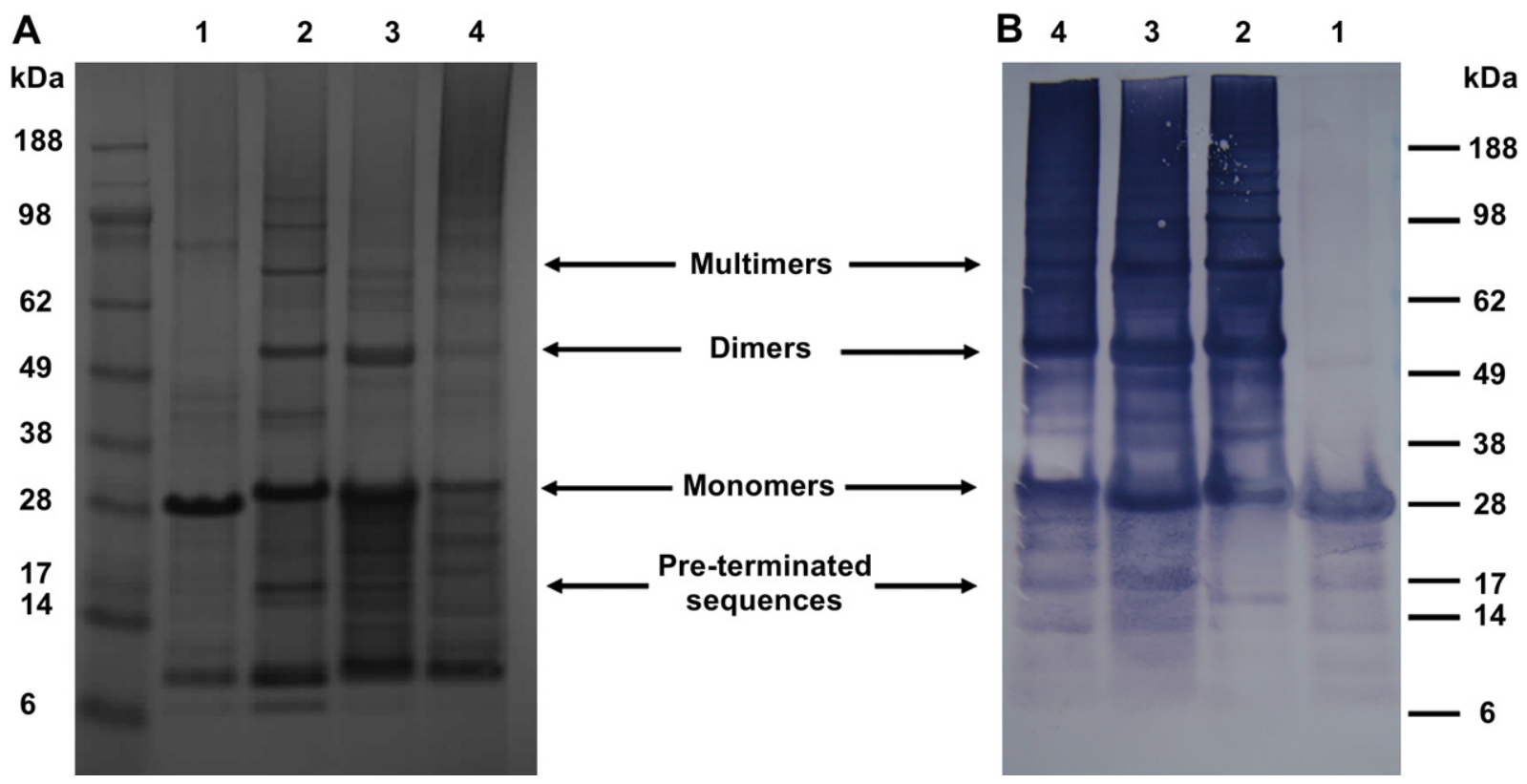

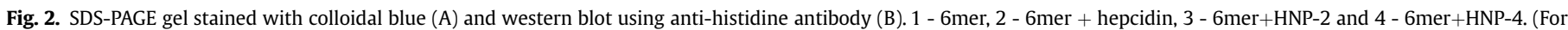
interpretation of the references to color in this figure legend, the reader is referred to the web version of this article).

\subsection{Circular dichroism spectroscopy}

CD spectroscopy was carried out for the four recombinant proteins, 6 mer+HNP-2, 6mer+HNP-4, 6mer + hepcidin and 6mer, in phosphate buffer ( $\mathrm{pH} 7.4)$. The spectra of the 6 mer indicated a dominant $\beta$-hairpin conformation characterized by a negative ellipticity with a minimum at approximately $203 \mathrm{~nm}$ (Fig. 7). In the case of 6 mer+HNP-2, 6mer+HNP-4 and 6 mer + hepcidin the spectra suggested the presence of both $\beta$ and $\alpha$ conformations with two minima at 204-208 and $220 \mathrm{~nm}$ [54-57].

\subsection{Cytotoxicity}

Cell viability/proliferation with the SaOs- 2 cells was measured after 3 days of culture using the Alamar Blue assay. The results indicated that there were no significant differences $(p<0.05)$ in cell viability/proliferation between cells cultured on 6 mer+HNP-2, 6mer+HNP-4, 6mer + hepcidin and 6mer films. Furthermore, when cell viability/proliferation results (expressed in cell number) for 6mer+HNP-2, 6mer+HNP-4 and 6mer + hepcidin films were compared with the results for the positive control TCP, only the 6 mer+HNP-4 films had a cell number significantly lower than TCP, $p<0.05$ (Fig. 8).

\section{Discussion}

The design and successful expression of three new chimeric proteins is presented through the fusion of the consensus repeat for spider silk protein MaSp1 (6mer) with hepcidin, HNP-2 and HNP-4 (Fig. 1). SDS-PAGE and Western blots showed the presence of bands around $28 \mathrm{kDa}$ (Fig. 2). The difference between the expected and the observed molecular weights for 6 mer+HNP-2 (24.6 kDa), 6 mer+HNP-4 (25 kDa) and 6mer + hepcidin (24.1 kDa) proteins is probably due to the formation of cysteine bridges which interfere with the migration of the proteins during electrophoresis and also lead to the formation of multimers. This behavior was also detected for other proteins such as bone morphogenetic proteins with six cysteine residues involved in the formation of intra and intermolecular disulphide bonds [58,59]. Furthermore, additional DLS measurements with silk proteins in SDS solution showed the formation of aggregates (data not shown) which can also interfere with the migration of these proteins during electrophoresis and lead to the formation of higher molecular weight structures as well as multimers.

ATR-FTIR was used to confirm the integrity of the 6 mer sequence in the three proteins (Fig. 3). The spectra collected for the three new proteins films, 6 mer+HNP-2, 6mer + HNP-4 and 6 mer + hepcidin, demonstrated the presence of $\beta$-sheet, with peaks in $1620-1630 \mathrm{~cm}^{-1}$ for amide I region and $1510-1530 \mathrm{~cm}^{-1}$ for amide II region $[46,52,53]$, after methanol treatment. Furthermore, spectral deconvolution indicated an increase of $\beta$-sheet content for 6 mer + HNP-2, 6mer+HNP-4 and 6mer + hepcidin, after methanol treatment, reaching values similar to those obtained for the $6 \mathrm{mer}$ control (Fig. 3); with $39.8 \%$ for 6 mer+HNP-2, $40.8 \%$ for the 6 mer, $42.8 \%$ for 6 mer $+\mathrm{HNP}-4$ and $41.9 \%$ in the case of 6 mer + hepcidin. These data demonstrate that the core self-assembling spider silk domain retained function related to the generation of $\beta$-sheet crystals in these new fusion systems. This is important for the material performance of these new proteins to attain self-standing material formats, such as the films studied here.

The three new fusion proteins, 6mer + HNP-2, 6mer + HNP-4, $6 \mathrm{mer}+$ hepcidin, also retained antimicrobial activity attributed to the inserted motifs HNP-2, HNP-4 and hepcidin, respectively (Figs. 4 and 5). Previous studies have demonstrated the efficacy of HNP-2, HNP-4 and hepcidin against different strains of E. coli [32]. 6 mer+HNP-4 presented the highest antibacterial activity, except for the concentration $100 \mu \mathrm{g} / \mathrm{mL}$, whereas 6mer+HNP-2 manifested the lowest bactericidal activity. These data support the functional attributes of the antimicrobial component of the fusion proteins, the second critical component of the protein polymer designs, to add to the silk material properties above. Additionally, besides testing the concentrations of 10,50 and $100 \mu \mathrm{g} / \mathrm{mL}$ other 

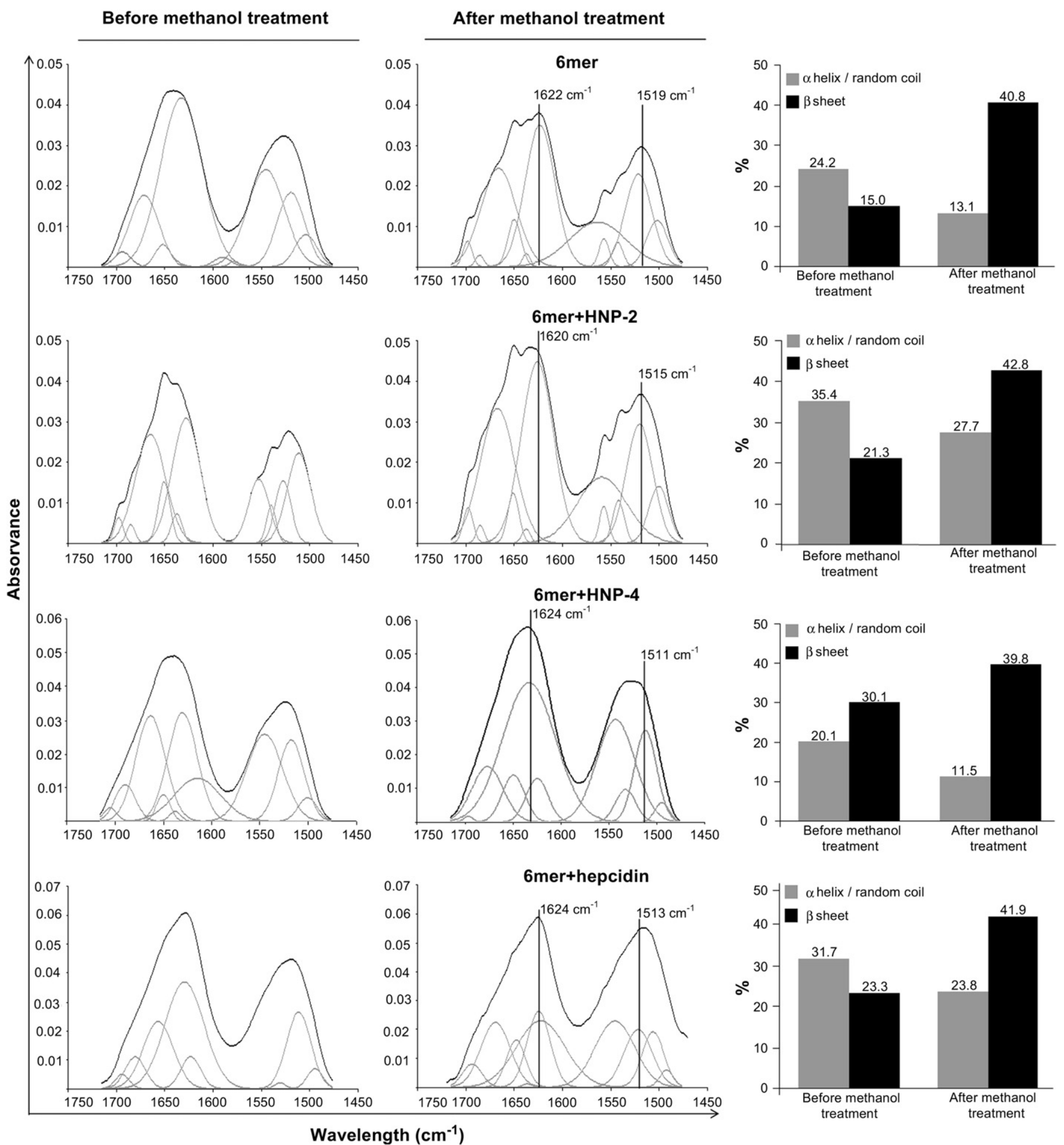

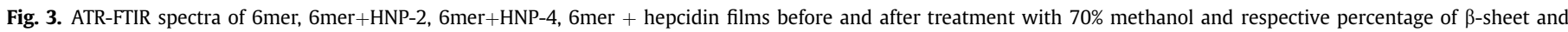
random coil/helix conformations after ATR-FTIR spectra deconvolution.

concentrations were also evaluated (data not shown for, 1 and $5 \mu \mathrm{g} /$ $\mathrm{mL}$ ), however the antimicrobial effect was either very reduced or nonexistent. For this reason the concentration of $10 \mu \mathrm{g} / \mathrm{mL}$ was selected in the present study as the lower concentration with an antimicrobial effect.
The three proteins had a decrease in their antimicrobial activity against $S$. aureus when compared to $E$. coli. This reduction in activity was also detected previously in the case of hepcidin. Park and coworkers isolated two different hepcidin peptides, hepcidin 20 and hepcidin 25 , from human urine and tested their bactericidal activity 


\section{E. coli}
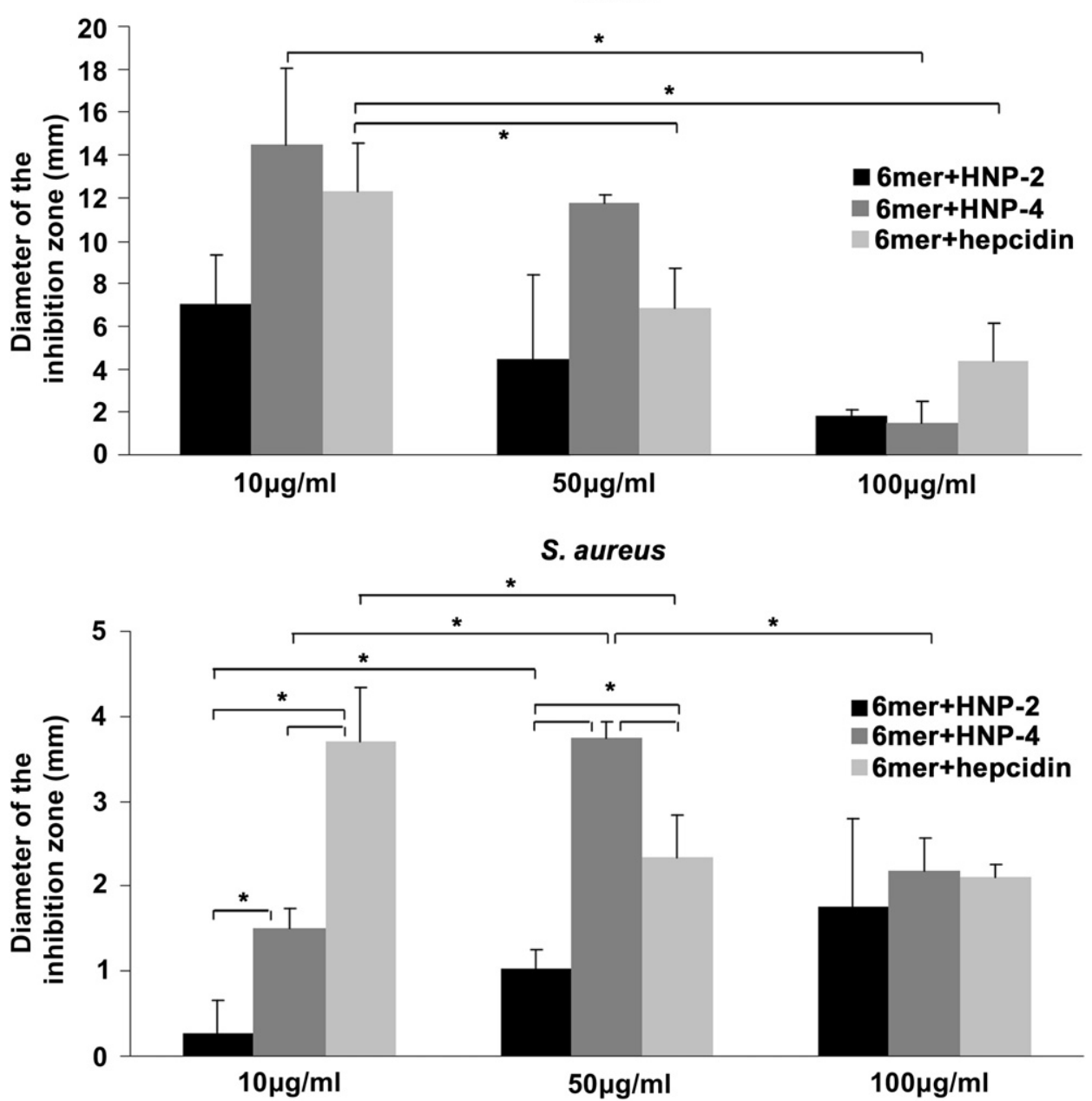

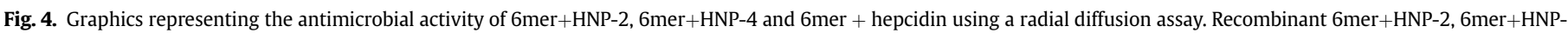

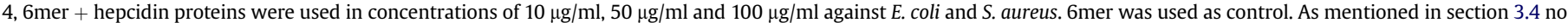
inhibitory effect was detected for the 6 mer protein and for that reason it was not included in the graphic representation. $*$ stands for $p<0.05$.

against different bacterial strains, E. coli ML35p and S. aureus. Both peptides were antimicrobial against E. coli ML35p but showed a reduction in activity against $S$. aureus [32]. Ericksen and colleagues [60] studied the activity of different $\alpha$-defensins (HNP-1, HNP-2, HNP-3, HNP-4, HD-5 and HD-6) against different bacterial strains and demonstrated that HNP-4 was the most effective against Gram- bacterial strains, one of which was E. coli ATCC 25922, the same strain as used in this present study.

Furthermore, in the present work for a concentration of $10 \mu \mathrm{g} / \mathrm{mL}$ the $6 \mathrm{mer}+$ hepcidin was more efficient against S. aureus than the other two proteins. However, with an increase in the protein concentration from 10 to $50 \mu \mathrm{g} / \mathrm{mL}$ the $6 \mathrm{mer}+\mathrm{HNP}-4$ became more effective. For both $E$. coli and S. aureus $6 \mathrm{mer}+\mathrm{HNP}-2$ proved to be the less bactericidal. Wilde and colleagues [61] compared the antimicrobial activities of HNP-4 and a mixture of HNP-1, HNP-2 and HNP-3 and concluded that HNP-4 was approximately 100 -fold more potent against Gram- E. coli and about 4-fold more potent against Gram+Streptococcus faecalis.This difference in efficacy may be one of the reasons why human neutrophils produce HNP-1, HNP-2 and HNP-3 at a 60-fold greater abundance when compared with the production of HNP-4 [60,62]. These results are similar to those obtained in the present work where 6mer+HNP-4 had higher antimicrobial activity when compared with 6mer+HNP-2.

Additionally, in order to facilitate the comparison between the present study and previous studies, using the same antimicrobial domains, the peptide concentrations studied here were kept within the same range of concentrations as those used previously $[34,35,60,61]$. However, in the present study and in contrast to what was observed in previous reports, the antimicrobial activity of the new chimeric proteins was not always concentration dependent. The presence of the 6mer silk domain explains this behavior, since silk proteins are known to aggregate in solution with increased concentration. The 6 mer protein, similar to the silk fibroin collected from the silk worm Bombyx mori, is rich in hydrophobic amino acids having a high percentage of the hydrophobic amino acids alanine and glycine. The presence of these hydrophobic cores induce the assembly of 6 mer+HNP-2, 6mer+HNP-4 and 6 mer + hepcidin proteins toward the more thermodynamically stable assembly resulting in a structural reorganization with reduction of exposure of hydrophobic residues [63]. In the case of the silk domains, this stability is achieved by self-assembly or by aggregation. In the present study a relationship between protein concentration and size of the aggregates was found as measured by DLS (Fig. 6). The 6 mer 
6mer against $E$. coli
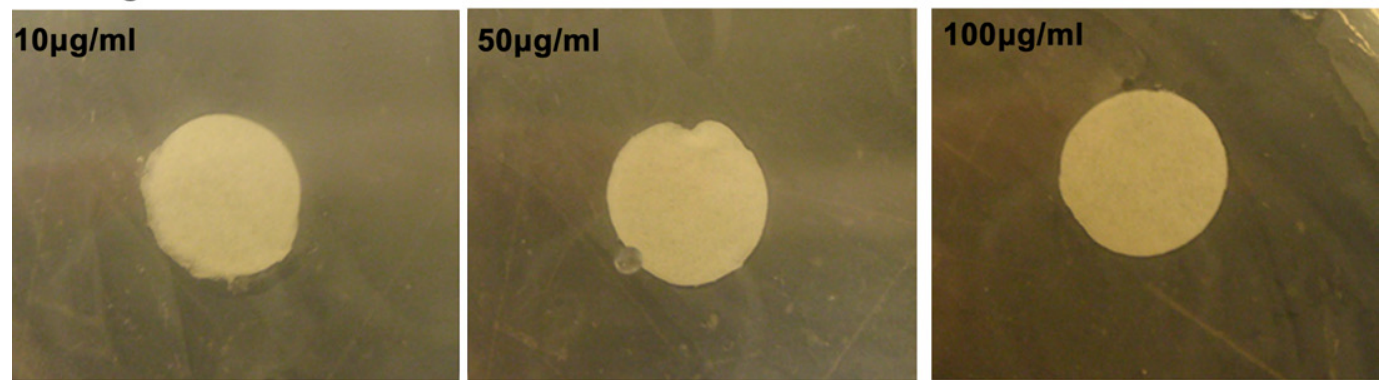

6mer+HNP-2 against $E$. coli
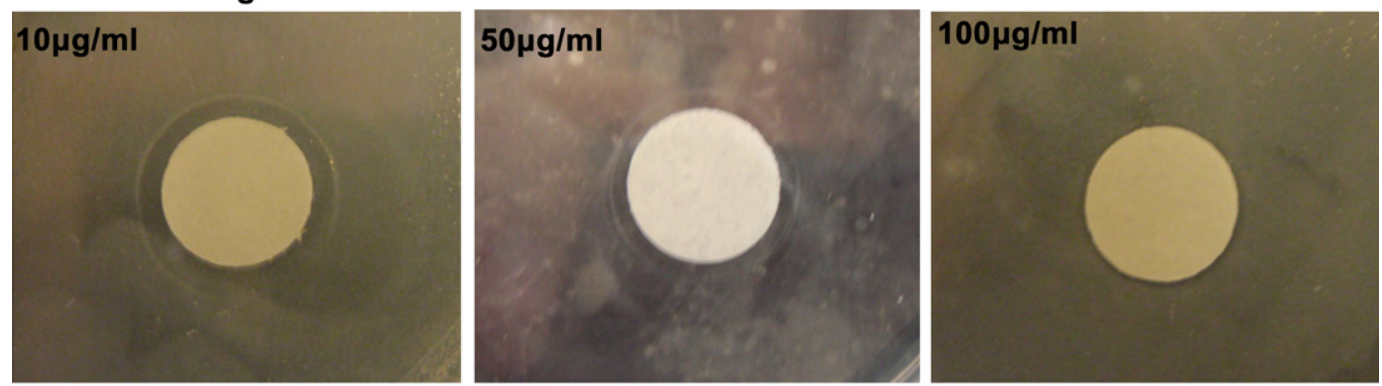

6mer+HNP-4 against $E$. coli
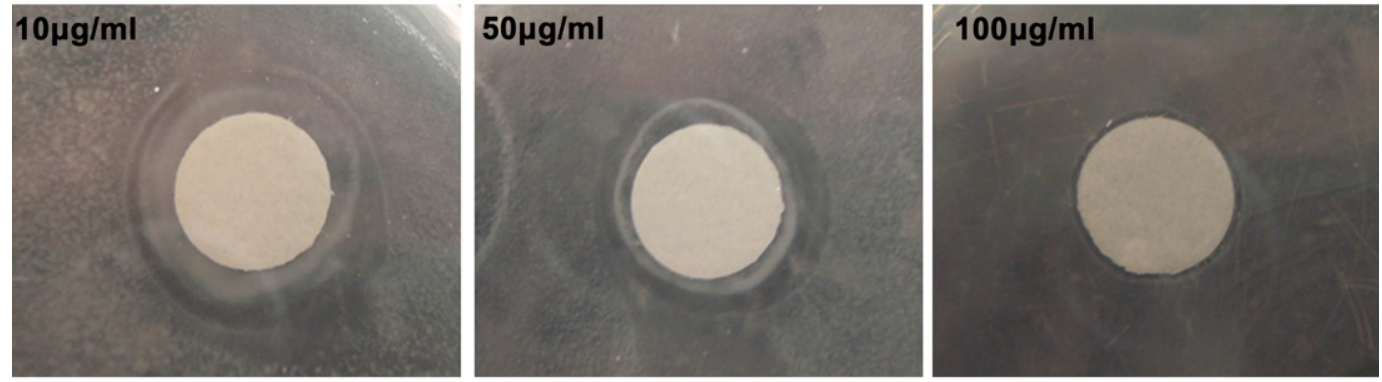

6mer+hepcidin against $E$. coli
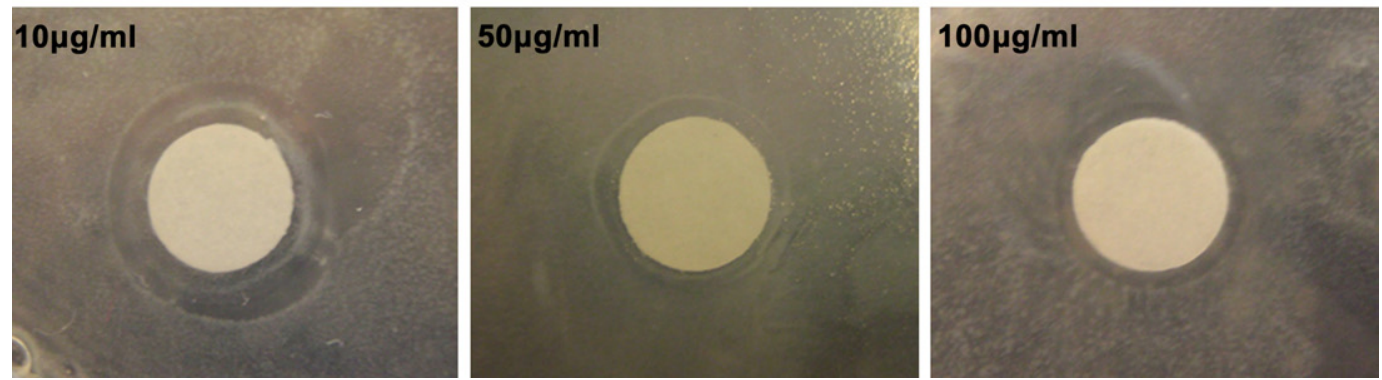

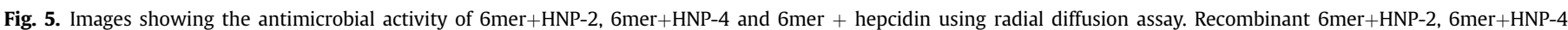

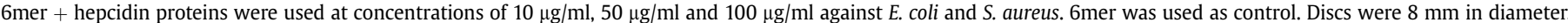

registered the highest values of aggregate size for the 50 and $100 \mu \mathrm{g} /$ $\mathrm{mL}$ concentrations with an average of 279 and $670 \mathrm{~nm}$, respectively. The other three proteins, 6mer+HNP-2, 6mer+HNP-4 and 6 mer + hepcidin, presented bi-modal distributions of sizes, except for $6 \mathrm{mer}+$ hepcidin at a concentration of $100 \mu \mathrm{g} / \mathrm{mL}$. In most cases the aggregate size generated by these proteins was smaller than in the case of the 6 mer alone. Moreover, the dependence between protein concentration and aggregates size for 6 mer+HNP-2, 6 mer + HNP-4 and 6 mer + hepcidin was not as evident as in the case of the 6 mer alone. This fact can be explained by the presence of the antimicrobial domain which increases the number of charged amino acid residues resulting in a reduction of the tendency of these proteins to aggregate by enhancing interactions with the solvent. A previous study where DLS was applied to the dynamic behavior and the conformational characteristics of $B$. mori silk fibroin demonstrated that this molecule forms large and stable aggregates even in very dilute solutions, supporting the tendency of silk molecules to form aggregates even in dilute conditions [64].

In the present work the decrease in antimicrobial activity of the new chimeric proteins as their concentration in solution increased can be explained by the occurrence of aggregation resulting in larger and more stable aggregates as protein concentration was increased. This interaction leads to a depletion of protein monomers in solution leaving fewer molecules free in solution to act against the bacteria. 
6mer against $S$. aureus
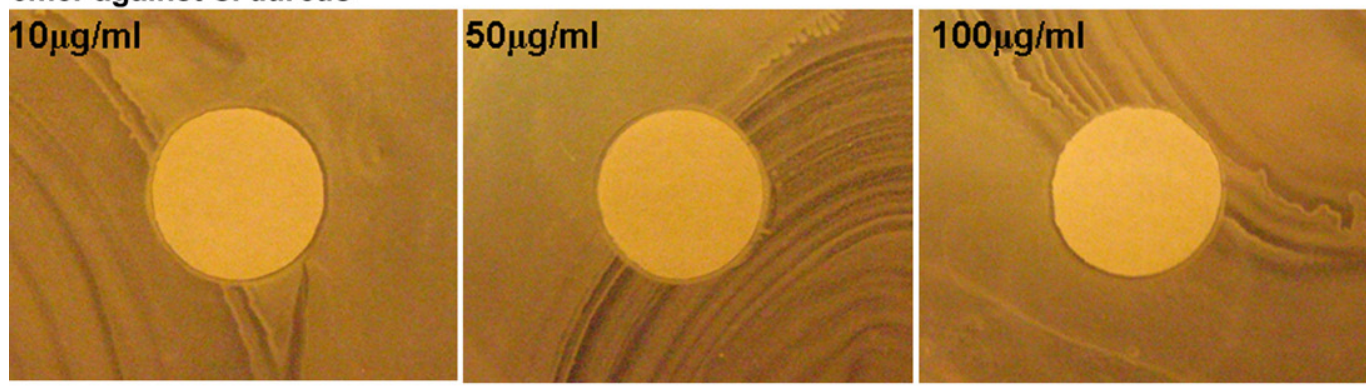

6 mer+HNP-2 against $S$. aureus
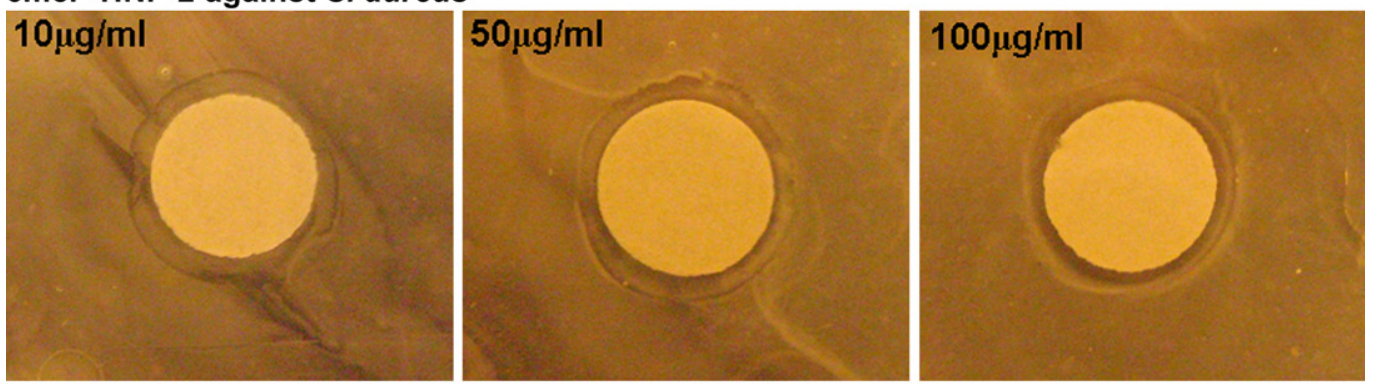

6 mer+HNP-4 against $S$. aureus
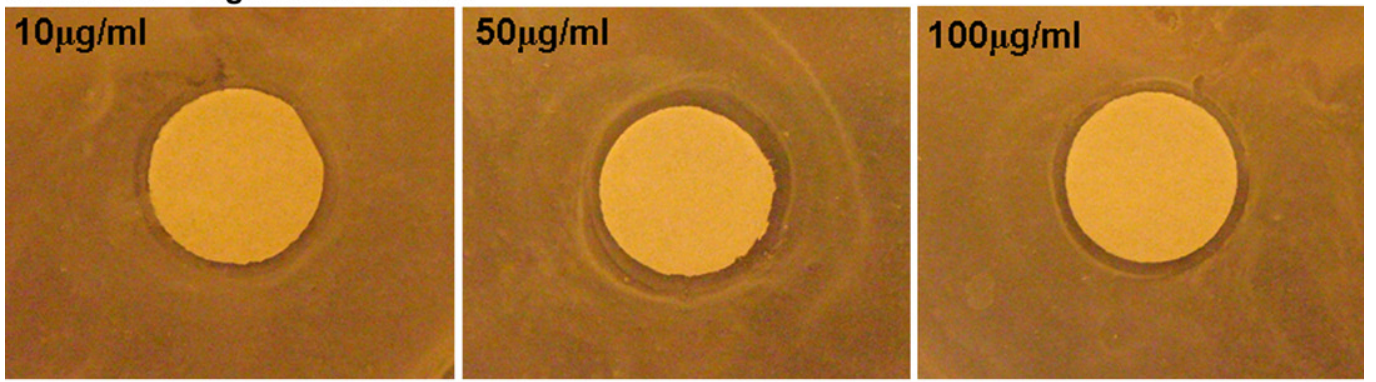

6 mer+hepcidin against $S$. aureus
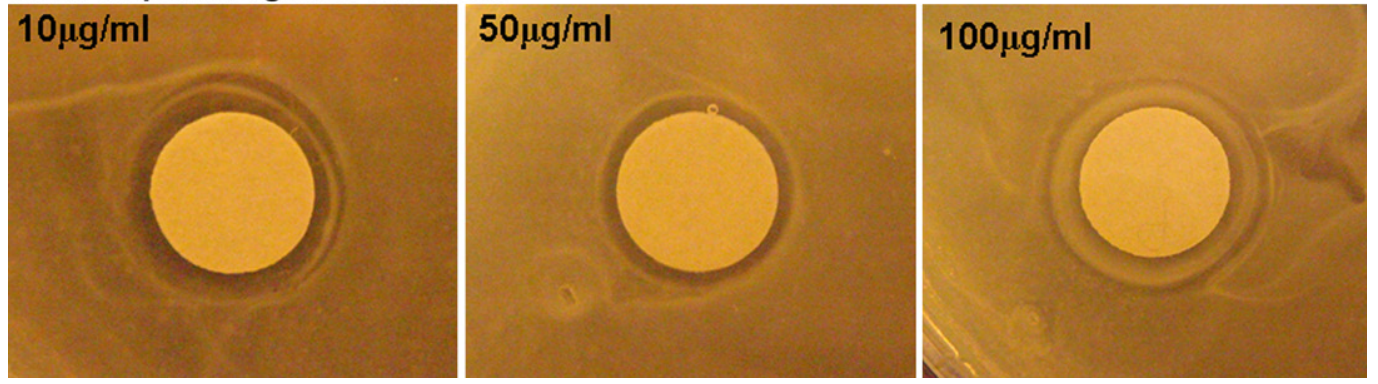

Fig. 5. (continued).

A possible reason for the decrease in antimicrobial activity is the absence of post-translational modifications leading to the formation of disulphide bonds between cysteine residues. The results obtained by Varkey and co-workers with HNP-1 peptides indicate that the presence of all three disulphide bonds and the order of connectivity are not essential for maintaining the activity of HNP-1. Also, linear HNP-1 peptides maintained antibacterial activity, however there was a 10-20-fold reduction in activity [54].

$\mathrm{CD}$ analyses indicated that in aqueous medium $6 \mathrm{mer}+\mathrm{HNP}-2$, 6 mer+HNP-4 and 6 mer + hepcidin displayed both $\beta$-hairpin and $\alpha$ conformations. In the case of the 6mer $\beta$-hairpin or $\beta$-sheet are the predominant conformations (Fig. 7) [54-57]. Previous CD conformation studies with synthetic HNP-1 in aqueous medium showed a spectrum with a minimum of $205 \mathrm{~nm}$ indicating the presence of $\beta$ conformation [57]. $\beta$ structure was also observed for HNP-1 peptides with two or three disulphide bonds [57]. These spectra have a minimum at $215 \mathrm{~nm}$ and differ from the ideal $\beta$ sheet spectra due to distortions and structural flexibility [57]. Additionally, a later study also with HNP-1 peptides dissolved in water showed spectra characteristic of an unordered structure. However, when these peptides are dissolved in sodium dodecyl sulphate or trifluoroethanol their spectra showed the presence of both $\beta$ and $\alpha$ conformations with minimums at 205 and $223 \mathrm{~nm}$ [54], very similar to the spectra obtained for 6 mer + HNP-2 and 

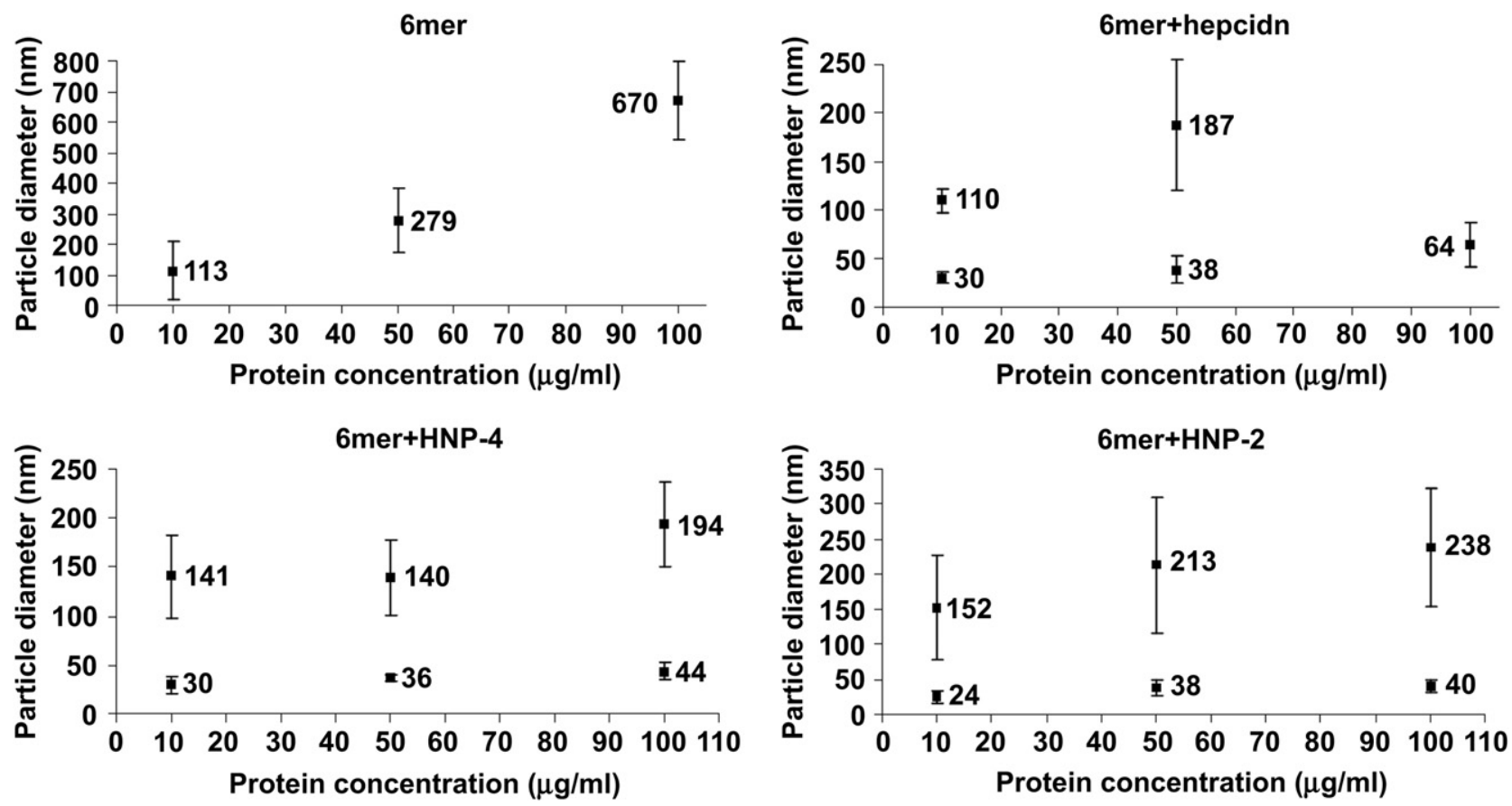

Fig. 6. DLS measures of particle diameter $(\mathrm{nm})$ as a function of protein concentration.

6 mer+HNP-4 proteins in the present study. In the case of hepcidin a previous study showed a CD spectrum for this peptide in phosphate buffer ( $\mathrm{pH} 7.4$ ) with $\beta$-turns, loops and $\beta$-sheet [32]. In the present study the spectrum for 6 mer + hepcidin showed both $\beta$ and $\alpha$ conformations.

For quantitative evaluation of the cytotoxic response to the chimeric proteins, the osteosarcoma cell line SaOs-2 was cultured on 6 mer+HNP-2, 6mer+HNP-4 and 6 mer + hepcidin films. The 6 mer+HNP-2 and 6 mer + hepcidin $2 \%$ films showed the same

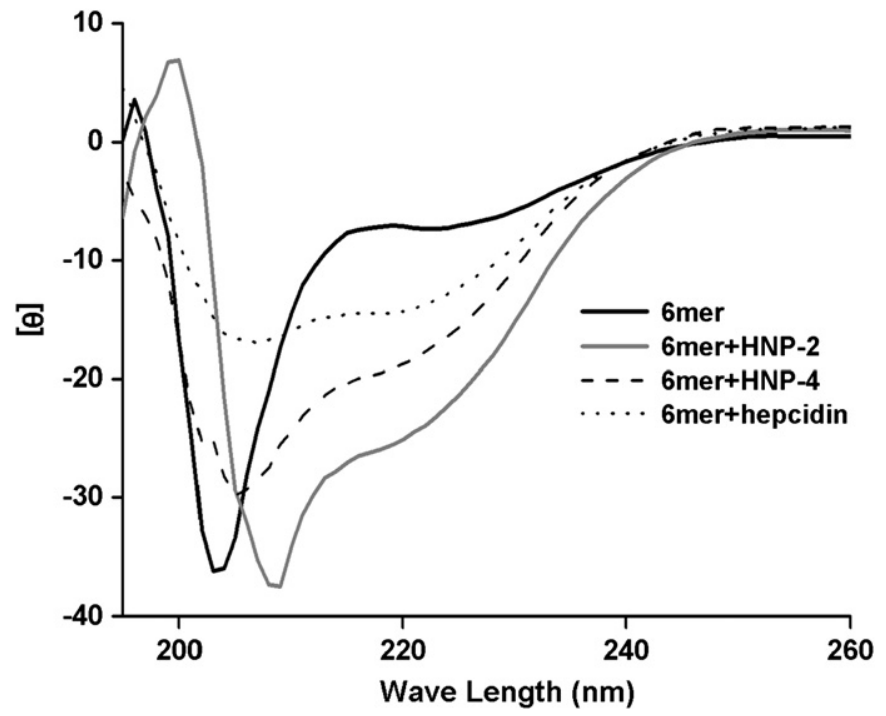

Fig. 7. $\mathrm{CD}$ spectra for the recombinant $6 \mathrm{mer}+\mathrm{HNP}-2,6 \mathrm{mer}+\mathrm{HNP}-4,6 \mathrm{mer}+$ hepcidin and $6 \mathrm{mer}$ ability as TCP to support viable cells $(p>0.05)$, while the 6 mer+HNP-4 films showed a significant difference $(p<0.05)$ from TCP (Fig. 8). No significant difference was observed between 6mer+HNP-2, 6mer+HNP-4, 6mer + hepcidin and 6mer films. These results indicated that these chimeric proteins, when processed into films, are capable of supporting cell proliferation, and the bactericidal activity does not impact mammalian cell function.

Many drug delivery systems for antibiotics have been described. Hydroxyapatite microspheres can be loaded with an antibiotic and

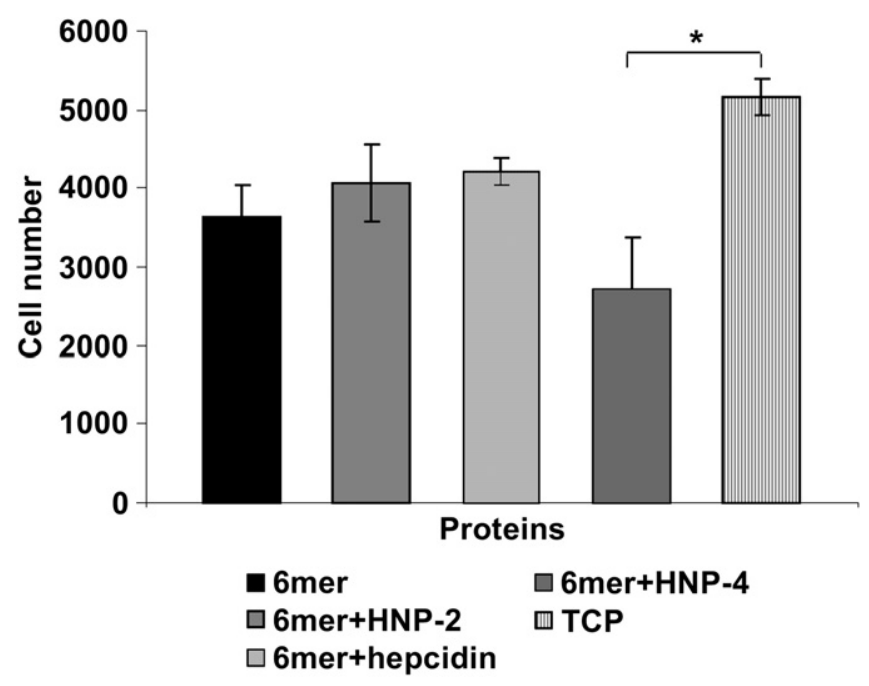

Fig. 8. Alamar blue for cells cultured on $6 \mathrm{mer}+\mathrm{HNP}-2,6 \mathrm{mer}+\mathrm{HNP}-4,6 \mathrm{mer}+$ hepcidin and 6 mer films after three days. TCP stands for tissue culture plastic, used as a positive control, and $*$ stands for $p<0.05$. 
used as a local drug delivery system for the treatment of periodontitis [65], chronic osteomyelitis [66], as just two examples. Nonetheless, hydroxyapatite-carrying systems tend to have a initial burst releasing the entire antibiotic in the first hours [65] and in many cases the antibiotics elute only for a short period of time $[67,68]$. This can be problematic if the final purpose is to obtain a more controlled release of the drug through time. In recent studies, different biopolymers have also been tested for potential applications as drug delivery systems. Silk fibroin [69,70], collagen $[71,72]$ and hyaluronic acid [73] are examples of natural polymers that have been used as a carrier systems for growth factors, such as bone morphogenetic proteins (BMPs), and antibiotics, in the form of micro-particles, membranes and scaffolds.

Antibiotic-doped biomaterials can be used to address growing concerns with the selection and spreading of multiresistant pathogens [74]. Antimicrobial peptides, as new chemotherapeutic molecules due to their activity against different types of microorganisms, are also important options, including antimicrobial functions as well as immune response [75] and wound repair [20] impacts. However, due to their peptidic nature these biomolecules are more susceptible to proteolytic digestion [76]. Therefore, their combination with a suitable delivery system, such as the one presented in this work, may represent an advantage by decreasing proteolitic digestion [77] and by allowing for more controlled release of these peptides to prolong effectiveness over time. This more controlled release is important in maintaining regional or localized effects, more precisely at the interface between the implant/host tissues, where bacterial colonization and posterior inflammation development first take place [74].

\section{Conclusions}

The present study outlines the formation of new silk-based chimeric proteins with antimicrobial potential. Secondary structure analysis, performed by ATR-FTIR, indicated that silk maintains $\beta$-sheet formation capability even after adding the antimicrobial domains, HNP-2, HNP-4 and hepcidin. The maintenance of the capacity to form $\beta$-sheet is important, since these physical crosslinks are responsible for the exceptional mechanical properties, stability and slow degradability of silk. Moreover, activity tests against Gram- and Gram + organisms showed that the antimicrobial domains present in 6mer+HNP-2, 6mer+HNP-4 and 6 mer + hepcidin proteins maintained bactericidal activity. Cytotoxicity/proliferation studies demonstrated that the new proteins were capable of sustaining the proliferation of mammalian cells. These new chimeric proteins suggest a new multifunctional approach to generate biomaterials with useful properties, in this case, control of infections due to the addition of the antimicrobial peptides.

\section{Acknowledgments}

The authors acknowledge Olena Rabotyagova for advice in protein sequence design. Sílvia Gomes thanks the Portuguese Foundation for Science and Technology (FCT) for providing her a PhD grant (SFRH/BD/28603/2006). This work was carried out under the scope of the European NOE EXPERTISSUES (NMP3-CT2004-500283), the FIND \& BIND project funded by the agency EUEC (FP7 program), the FCT R\&D project ProteoLight (PTDC/FIS/ $68517 / 2006$ ) funded by the FCT agency, the Chimera project (PTDC EBB-EBI/109093/2008) funded by the FCT agency, the NIH (P41 EB002520) Tissue Engineering Resource Center and the $\mathrm{NIH}$ (EB003210 and DE017207).

\section{References}

[1] Hodgkinson R. Internal fixation of fractures of long bones with metallic devices. Med J Aust 1961;48(1):691-3.

[2] Osbon O, Lilly G, Thompson C. TJost. Bone grafts with surface decalcified allogeneic and particulate autologous bone: report of cases. J Oral Surg 1977;35(4):276-84.

[3] Kohna J, Welshb WJ, Knight D. A new approach to the rationale discovery of polymeric biomaterials. Biomaterials 2007;28(29):4171-7.

[4] Williams DJ, Sebastine IM. Tissue engineering and regenerative medicine: manufacturing challenges. IEE Proc Nanobiotechnol 2005;156(6):207-10.

[5] Santos MI, Pashkuleva I, Alves CM, Gomes ME, Fuchs S, Unger RE, et al. Surface-modified 3D starch-based scaffold for improved endothelialization for bone tissue engineering. J Mater Chem 2009;19(24):4091-101.

[6] Santo VE, Frias AM, Carida M, Cancedda R, Gomes ME, Mano JF, et al. Carrageenan-based hydrogels for the controlled delivery of PDGF-BB in bone tissue engineering applications. Biomacromolecules 2009;16(6):1392-401.

[7] Reis RL, Neves NM, Mano JF, Gomes ME, Marques AP, Azevedo HS. Naturalbased polymers for biomedical applications. Woodhead Publishing; 2008.

[8] Mano JF, Silva GA, Azevedo HS, Malafaya PB, Sousa RA, Silva SS, et al. Natural origin biodegradable systems in tissue engineering and regenerative medicine: present status and some moving trends. J R Soc Interface 2007:4 (17):999-1030.

[9] Harris LD, Kim B-S, Mooney DJ. Open pore biodegradable matrices formed with gas foaming. J Biomed Mater Res B Appl Biomater 1998;42(3):396-402.

[10] Suh H. Recent advances in biomaterials. Yonsei Med J 1998;39(2):87-96.

[11] Huang J, Wong C, George A, Kaplan DL. The effect of genetically engineered spider silk-dentin matrix protein 1 chimeric protein on hydroxyapatite nucleation. Biomaterials 2007;28(14):2358-67.

[12] Yang L, Hedhammar M, Blom T, Leifer K, Johansson J, Habibovic P, et al. Biomimetic calcium phosphate coatings on recombinant spider silk fibres. Biomed Mater 2010;5(4):1-10.

[13] Foo CWP, Patwardhan SV, Belton DJ, Kitchel B, Anastasiades D, Huang J, et al. Novel nanocomposites from spider silk-silica fusion (chimeric) proteins. Proc Natl Acad Sci USA 2006;103(25):9428-33.

[14] Marr AK, Gooderham WJ, Hancock REW. Antibacterial peptides for therapeutic use: obstacles and realistic outlook. Curr Opin Pharmacol 2006;6 (5):468-72.

[15] Huang HW. Action of antimicrobial peptides: two-state model. Biochemistry 2000;39(29):8347-52.

[16] Shai Y. Mechanism of the binding, insertion and destabilization of phospholipid bilayer membranes by alpha-helical antimicrobial and cell non-selective membrane-lytic peptides. Biochim Biophys Acta 1999;1462(1-2):55-70.

[17] Hancock REW, Chapple DS. Peptide antibiotics. Antimicrob Agents Chemother 1999;43:1317-23.

[18] Befus AD, Mowat C, Gilchrist M, Hu J, Solomon S, Bateman A. Neutrophil defensins induce histamine secretion from mast cells: mechanisms of action. J Immunol 1999;163(2):947-53.

[19] Grigat J, Soruri A, Forssmann U, Riggert J, Zwirner J. Chemoattraction of macrophages, $\mathrm{T}$ lymphocytes, and mast cells is evolutionarily conserved within the human $\alpha$-defensin family. J Immunol 2007;179(6):3958-65.

[20] Aarbiou J, Verhoosel RM, Van Wetering S, De Boer WI, Van Krieken JH, Litvinov SV, et al. Neutrophil defensins enhance lung epithelial wound closure and mucin gene expression In vitro. Am J Respir Cell Mol Biol 2004;30 (2):193-201.

[21] Aarbiou J, Ertmann M, Wetering S, Noort P, Rook D, Rabe KF, et al. Human neutrophil defensins induce lung epithelial cell proliferation in vitro. J Leukoc Biol 2002;72(1):167-74.

[22] Murphy CJ, Foster BA, Mannis MJ, Selsted ME, Reid TW. Defensins are mitogenic for epithelial cells and fibroblasts. J Cell Physiol 1993;155(2):408-13.

[23] Chavakis T, Cines DB, Rhee J-S, Liang OD, Schubert U, Hammes H-P, et al. Regulation of neovascularization by human neutrophil peptides ( $\alpha$-defensins): a link between inflammation and angiogenesis. FASEB J 2004;18 (11):1306-8.

[24] Bals R. Epithelial antimicrobial peptides in host defense against infection. Respir Res 2000;1(3):141-50.

[25] Schneider JJ, Unholzer A, Schaller M, Schäfer-Korting M, Korting HC. Human defensins. J Mol Med 2005;83(8):587-95.

[26] Smet KD, Contreras R. Human antimicrobial peptides: defensins, cathelicidins and histatins. Biotechnol Lett 2005;27(18):1337-47.

[27] Selsted ME, Harwig SSL, Ganz T, Schilling JW, Lehrer RI. Primary structures of three human neutrophil defensins. J Clin Invest 1985;76(4):1436-9.

[28] Jones DE, Bevins CL. Paneth cells of the human small intestine express an antimicrobial peptide gene. J Biol Chem 1992;267(15):23216-25.

[29] Pazgier M, Lubkowski J. Expression and purifcation of recombinant human $\alpha$ defensins in Escherichia coli. Protein Expr Purif 2006;49(1):1-8.

[30] Wu Z, Cocchia F, Gentlesa D, Ericksena B, Lubkowskib J, DeVicoa A, et al. Human neutrophil a-defensin 4 inhibits HIV-1 infection in vit. FEBS Lett 2005;579(1):162-6.

[31] Krause A, Neitz S, Mägert H, Schulz A, Forssmann W, Schulz-Knappe P, et al. LEAP-1, a novel highly disulfide-bonded human peptide, exhibits antimicrobial activity. FEBS Lett 2000;480:147-50.

[32] Park CH, Valore EV, Waring AJ, Ganz T. Hepcidin, a urinary antimicrobial peptide synthesized in the liver. J Biol Chem 2001;276(11):7806-10. 
[33] Koliaraki V, Marinou M, Samiotaki M, Panayotou G, Pantopoulos K, Mamalaki A. Iron regulatory and bactericidal properties of human recombinant hepcidin expressed in Pichia pastori. Biochimie 2008;90(5):1-10.

[34] Wallace DF, Jones MD, Pedersen P, Rivas L, Sly LI, Subramaniam VN. Purification and partial characterisation of recombinant human hepcidin. Biochimie 2006;88(1):31-7.

[35] Zhang H, Yuan Q, Zhu Y, Ma R. Expression and preparation of recombinant hepcidin in Escherichia coli. Protein Expr Purif 2005;41(2):409-16.

[36] Xu M, Lewis RV. Structure of a protein superfiber: spider dragline silk. Proc Natl Acad Sci USA 1990;87(18):7120-4.

[37] Scheibel T. Spider silks: recombinant synthesis, assembly, spinning, and engineering of synthetic proteins. Microb Cell Fact 2004;3(1):14-24

[38] Cao Y, Wang B. Biodegradation of silk biomaterials. Int J Mol Sci 2009;10 (4):1514-24

[39] Guerreiro CIPD, Fontes CMGA, Gama M, Domingues L. Escherichia coli expression and purification of four antimicrobial peptides fused to a family 3 carbohydrate-binding module (CBM) from Clostridium thermocellum. Protein Expr Purif 2008;59:161-8.

[40] Ramos R, Domingues L, Gama M. Escherichia coli expression and purification of LL37 fused to a family III carbohydrate-binding module from Clostridium thermocellum. Protein Expr Purif 2010;71(1):1-7.

[41] Haynie SL, Crum GA, Doele BA. Antimicrobial activities of amphiphilic peptides covalently bonded to a water-insoluble resin. Antimicrob Agents Chemother 1995;39(2):301-7.

[42] Bagheri M, Beyermann M, Dathe M. Immobilization reduces the activity of surface-bound cationic antimicrobial peptides with no influence upon the activity spectrum. Antimicrob Agents Chemother 2009;53(3):1132-41.

[43] Appendini P, Hotchkiss JH. Surface modification of poly(styrene) by the attachment of an antimicrobial peptide. J Appl Polym Sci 2001;81(3):609-16.

[44] Choa W-M, Joshia BP, Choa H, Lee K- H. Design and synthesis of novel antibacterial peptide-resin conjugates. Bioorg Med Chem Lett 2007;17 (21):5772-6

[45] Gabriel M, Nazmi K, Veerman EC, Amerongen AVN, Zentner A. Preparation of LL-37-grafted titanium surfaces with bactericidal activity. Bioconjug Chem 2006;17(2):548-50.

[46] Rabotyagova O, Cebe P, Kaplan DL. Self-assembly of genetically engineered spider silk block copolymers. Biomacromolecules 2009;10(2):229-36.

[47] Yan S-Z, Beeler JA, Chen Y, Shelton RK, Tang W-J. The regulation of type 7 adenylyl cyclase by Its $\mathrm{C} 1 \mathrm{~b}$ region and Escherichia coli peptidylprolyl isomerase, SlyD. J Biol Chem 2001;276(11):8500-6.

[48] Hu X, Kaplan D, Cebe P. Determining beta-sheet crystallinity in fibrous proteins by thermal analysis and infrared spectroscopy. Macromolecules 2006;39(18):6161-70.

[49] Arrondo J, Goñi F. Structure and dynamics of membrane proteins as studied by infrared spectroscopy. Prog Biophys Mol Biol 1999;72(4):367-405.

[50] Lehrer RI, Rosenman M, Harwig SSSL, Jackson R, Eisenhauer P. Ultrasensitive assays for endogenous antimicrobial polypeptides. J Immunol Methods 1991:137(2):167-73.

[51] Lancaster MV, Fields RD, inventors. antibiotic and cytotoxic drug susceptibility assays using resazurin and poising agents. USA Patent No. 5501959, 1996.

[52] Foo CWP, Bini E, Huang J, Lee SY, Kaplan DL. Solution behavior of synthetic silk peptides and modified recombinant silk proteins. Appl Phys A Mater Sci Process 2006;82:193-203.

[53] Rabotyagova OS, Cebe P, Kaplan DL. Role of polyalanine domains in $\beta$-sheet formation in spider silk block copolymers. Macromol Biosci 2010;10(1):49-59.

[54] Varkey J, Nagaraj R. Antibacterial activity of human neutrophil defensin HNP-1 analogs without cysteines. Antimicrob Agents Chemother 2005;49(11):4561-6.

[55] Kelly SM, Jess TJ, Price NC. How to study proteins by circular dichroism. Biochim Biophys Acta 2005;1751(2):119-39.
[56] Cerpa R, Cohen FE, Kuntz ID. Conformational switching in designed peptides: the helix/sheet transition. Fold Des 1996;1(2):91-101.

[57] Mamdal M, Nagaraj R. Antibacterial activities and conformations of synthetic $\alpha$-defensin HNP-1 and analogs with one, two and three disulfite bridges. J Pept Res 2002;59:95-104.

[58] Bessa PC, Pedro AJ, Klosch B, Nobre A, Van Griensven M, Reis RL, et al. Osteoinduction in human fat-derived stem cells by recombinant human bone morphogenetic protein-2 p.oduced in Escherichia coli. Biotechnol Lett 2008;30(1):15-21.

59] Long S, Truong L, Bennett K, Phillips A, Wong-Staal F, Ma H. Expression, purification, and renaturation of bone morphogenetic protein-2 from Escherichia coli. Protein Expr Purif 2006;46(2):374-8.

[60] Ericksen B, Wu Z, Lu W, Lehrer RI. Antibacterial activity and specificity of the six human $\alpha$-defensins. Antimicrob Agents Chemother 2005:49(1):269-75.

[61] Wilde CG, Griffith JE, Marra MN, Snable JL, Scott RW. Purification and characterization of human neutrophil peptide 4 , a novel member of the defensin family. J Biol Chem 1989;264(5):11200-3.

[62] Harwig SS, Park AS. Lehrer. RI. Characterization of defensin precursors in mature human neutrophils. Blood 1992;79:1532-7.

63] Calamai M, Canale C, Relini A, Stefani M, Chiti F, Dobson CM. Reversal of protein aggregation provides evidence for multiple aggregated states. J Mol Biol 2005;346(2):603-16.

[64] Hossain KS, Nemoto N. Dynamic and static light scattering of dilute aqueous solutions of silk fibroin collected from Bombyx mori silkworms. Langmuir 1999;15:4114-9.

[65] Ferraz MP, Mateus AY, Sousa JC, Monteiro FJ. Nanohydroxyapatite microspheres as delivery system for antibiotics: release kinetics, antimicrobia activity, and interaction with osteoblasts. J Biomed Mater Res A 2007;81 (4):994-1004.

[66] Krisanapiboon A, Buranapanitkit B, Oungbho K. Biocompatability of hydroxyapatite composite as a local drug delivery system. J Orthop Surg 2006;14(3):315-8.

[67] Kanellakopoulou K, Giamarellos-Bourboulis EJ. Carrier systems for the local delivery of antibiotics in bone infections. Drugs 2000;59(6):1223-32.

[68] Shinto Y, Uchida A, Korkusuz F, Araki N, Ono K. Calcium hydroxyapatite ceramic used as a delivery system for antibiotics. J Bone Jt Surg 1992;74 (4):600-4.

[69] Bessa PC, Balmayor ER, Azevedo HS, Nürnberger S, Casal M, Van Griensven M et al. Silk fibroin microparticles as carriers for delivery of human recombinant BMPs. Physical characterization and drug release. J Tissue Eng Regen Med 2010;4(5):349-55.

[70] Lia C, Veparia C, Jin H-J, Kim HJ, Kaplan DL. Electrospun silk-BMP-2 scaffolds for bone tissue engineering. Biomaterials 2006;27(16):3115-24.

[71] Ruszczak Z, Friess W. Collagen as a carrier for on-site delivery of antibacterial drugs. Adv Drug Deliv Rev 2003;55(12):1679-98.

[72] Schlapp M, Friess W. Collagen/PLGA microparticle composites for local controlled delivery of gentamicin. J Pharm Sci 2003;92(11):2145-51.

[73] Luo Y, Kirker KR, Prestwich GD. Cross-linked hyaluronic acid hydrogel films: new biomaterials for drug delivery. J Control Release 2000;69(1):169-84.

[74] Campoccia D, Montanaro L, Speziale P, Arciola CR. Antibiotic-loaded biomaterials and the risks for the spread of antibiotic resistance following their prophylactic and therapeutic clinical use. Biomaterials 2010;31(25):6363-77.

[75] Ganz T. Defensins: antimicrobial peptides of innate immunity. Nature 2003;3:710-20

[76] Bruschi M, Pirri G, Giuliani A, Nicoletto SF, Baster I, Scorciapino MA, et al. Synthesis, characterization, antimicrobial activity and LPS-interaction properties of SB041, a novel dendrimeric peptide with antimicrobial properties. Peptides 2010;31(8):1459-67.

[77] Numata K, Subramanian B, Currie HA, Kaplan DL. Bioengineered silk proteinbased gene delivery systems. Biomaterials 2010;30(29):5775-84. 